\title{
Effect of Service Experience and Perceived Value on Patients Satisfaction with Special Hospitals for Mom and Children
}

\author{
Nurfitriani ${ }^{1}$, Irwandy ${ }^{1}$, Atjo Wahyu ${ }^{2}$ \\ nurfitnur2112@gmail.com \\ ${ }^{1}$ Hospital Management Division, Faculty of Public Health, Hasanuddin University, Indonesia \\ ${ }^{2}$ Occupational Health and Safety Section, Faculty of Public Health, Hasanuddin University, \\ Indonesia
}

Received: December 16, 2020

Received in revised: January 2, 2021

Accepted: January 12, 2020

\begin{abstract}
Patient satisfaction must be achieved in order to survive in the competitive hospital industry which tends to continue to grow beyond existing needs. This study aims to determine whether there is an effect of Service Experience and Perceived Value on patient satisfaction in the Inpatient Installation of the Regional Special Hospital of South Sulawesi Province (RSKD IA Pertiwi and RSKD IA Siti Fatimah). This type of research is a quantitative study using an observational study with a cross-sectional study design. The samples in this study were patients in the inpatient installation of the IA Pertiwi Regional Special Hospital (RSKD) and RSKD IA Siti Fatimah, totaling 130 respondents. The results showed that service experience based on functional clues variables, mechanic clues variables, humanistic clues variables, and perceived value affected patient satisfaction. It is recommended to every officer, both management and all employees, to maintain the dimensions of a good service experience, try to meet expectations, wants, and needs according to hospital standards, especially in the functional clues and humanistic clues dimensions by increasing the sensitivity of nurses in handling/care that can help complaints patients, there needs to be an increase in strategies in building customer value so that patients feel the pride felt by patients when they are treated in the hospital
\end{abstract}

Keywords: Service Experience, Functional Clues, Mechanic Clues, Humanistic Clues

\section{Introduction}

Patient satisfaction in health services is an important component of organizational performance in a hospital environment (Péfoyo \& Wodchis, 2013). Patient satisfaction refers to the extent to which the patient's expectations, goals, and preferences are met by health care providers (Huei et al., 2015). Greater patient satisfaction with treatment will result in patients obeying the doctor's orders, more loyal, positive word of mouth by the patient, reduced number of patient complaints, higher profits, higher patient return rates and more patient referrals (Zarei et al., 2015).

Based on several previous research results, it shows that patient satisfaction is greatly influenced by service experience (Guo, 2012; Yulianti, 2017). Meanwhile, Haeckel et al (2003) and Casper \& Leonard (2006) state that service clues affect satisfaction through perceptions formed in each service experience. In addition, perceived value also affects patient satisfaction.

Perceived values play an important role in increasing the level of patient satisfaction (Moliner, 2009). This indicates that patient satisfaction will be higher if the perceived value and quality 
exceeds the patient's expectations (Surydana, 2017). Customer perceived value can be described as an evaluation to compare perceptions of the perceived value and tangible results of the purchase experience (Chiang \& Lee, 2013). Meanwhile, Casper \& Leonard (2006) stated that satisfaction comes from the perception that is formed in each service experience when there is an interaction between the customer and the service provider. By interaction, customers assess their value not in the purchase stage but during the consumption or service use stage (Akbar et al., 2016). This experience is influenced by sensory and emotional clues that generate a perception, both rational and emotional, and affects satisfaction (Casper \& Leonard, 2006; Prabhu \& Kazi, 2016).

RSKD IA Siti Fatimah and RSKD IA Pertwi are special hospitals that provide services for mothers and children including pregnant women and newborns, whose care takes a long and continuous period from the beginning of pregnancy until the baby gets further services such as immunization and vaccines so that These patients or customers have received various services at the hospital. Patient satisfaction at the inpatient installation of RSKD IA Pertiwi shows the average level of patient satisfaction in 2016 to 2018 is $82.62 \%$ and in the Inpatient Installation of RSKD IA Siti Fatimah, South Sulawesi Province is 82\% (Ministry of Health Standard No. 90\%). Patient satisfaction is considered to affect the loyalty of service quality at the hospital.

Based on the problems and the results of previous research obtained, this study was conducted to see the effect of service experience and perceived value on patient satisfaction at the Inpatient Installation at RSKD IA Pertiwi and RSKD IA Siti Fatimah to further improve the quality of service and increase patient visits to the health services provided.

\section{Methods}

This type of research is a quantitative study with a Cross-Sectional Study approach. This research was conducted at RSKD IA Pertiwi and RSKD IA Siti Fatimah. The population in this study were all patients in the Inpatient Installation of RSKD IA Pertiwi and RSKD IA Siti Fatimah. The sample of this research is 130 people. The instrument used in data collection is a questionnaire, regarding the independent variables in the form of service experience and perceived value, while the dependent variable is the variable patient satisfaction.

Univariate analysis was conducted to obtain an overview of the research problem by describing each variable used in the study and the characteristics of the respondent. The univariate analysis consisted of descriptive analysis of the characteristics of the respondents, descriptive analysis of the research variables and analysis of the crosstabulation between the characteristics of the respondents and the research variables. Bivariate analysis was carried out to see the effect of two variables, namely between the independent variable and the dependent variable. The statistical test used was the Mann Whitney U Test.

\section{Results and Discussion}

Table 1. Frequency Distribution of General Characteristics of Respondents

\begin{tabular}{|l|c|c|c|c|}
\hline \multirow{2}{*}{$\begin{array}{c}\text { Respondent } \\
\text { Characteristics }\end{array}$} & \multicolumn{2}{|c|}{ RSIA Pertiwi } & \multicolumn{2}{c|}{ RSIA Siti Fatimah } \\
\cline { 2 - 5 } & $\mathbf{( n )}$ & $\mathbf{( \% )}$ & $\mathbf{( n )}$ & $(\boldsymbol{\%})$ \\
\hline Age Group (year) & - & - & 12 & 18.5 \\
\hline $15-20$ & 16 & 24.6 & $\mathbf{2 4}$ & $\mathbf{3 6 . 9}$ \\
\hline $21-25$
\end{tabular}




\begin{tabular}{|l|c|c|c|c|}
\hline $26-30$ & $\mathbf{3 8}$ & $\mathbf{5 8 . 5}$ & 17 & 26.2 \\
\hline $31-35$ & 7 & 10.8 & 7 & 10.8 \\
\hline $36-40$ & 4 & 6.2 & 5 & 7.7 \\
\hline $41-45$ & - & - & - & - \\
\hline Sex & - & - & - & - \\
\hline Male & 65 & 100 & 65 & 100 \\
\hline Female & 7 & 10.8 & - & - \\
\hline Education & 17 & 26.2 & 14 & 21.5 \\
\hline No School & 26 & 40.0 & 23 & 35.4 \\
\hline Elementary School & 9 & 13.8 & 20 & 30.8 \\
\hline Junior School & 6 & 9.2 & 8 & 12.3 \\
\hline High School & 7 & 10.8 & 2 & 3.1 \\
\hline Higher Education & 18 & 27.7 & 16 & 24.6 \\
\hline Employment & 1 & 1.5 & 25 & 38.5 \\
\hline Civil Servant & 36 & 55.4 & 13 & 20.0 \\
\hline General employees & 3 & 4.6 & 9 & 13.8 \\
\hline Traders & $\mathbf{6 5}$ & $\mathbf{1 0 0}$ & $\mathbf{6 5}$ & $\mathbf{1 0 0}$ \\
\hline House Wife & \multicolumn{5}{|l}{} \\
\hline Others & \multicolumn{5}{|l|}{} \\
\hline \multicolumn{7}{|l|}{ Total } &
\end{tabular}

Source: Primary data, 2020

Table 1 shows the frequency distribution based on the characteristics of the sample at the research location. It can be seen that most respondents at RSKD IA Pertiwi are in the 26-30year-old group, namely 38 respondents or $58.5 \%$, while most respondents at RSKD IA Siti Fatimah are in the age group. 21-25 years, as many as 24 respondents or $36.9 \%$ of the gender characteristics in RSKD IA Pertiwi, namely the female gender as many as 65 respondents or by $100 \%$, while the largest number of respondents in RSKD IA Siti Fatimah, namely the female gender as many as 65 respondents or equal to $100 \%$. From the characteristics of the latest education level, most respondents were in RSKD IA Pertiwi, namely the education level of SMP / SLTA as many as 26 respondents or by $40 \%$, while in RSKD IA Siti Fatimah, the education level of SMP / SLTA was 23 respondents or 35.4\%. From the job characteristics, most respondents were in RSKD IA Pertiwi, namely the work of IRT as many as 36 respondents or $55.4 \%$, while in RSKD IA Siti Fatimah, namely the work of traders as many as 235 respondents or $38.5 \%$.

Table 2. The effect of variable functional clues on patient satisfaction at the Inpatient Installation of RSKD I.A South Sulawesi Province

\begin{tabular}{|c|c|c|c|c|c|c|c|c|c|}
\hline \multirow{4}{*}{ Variable } & \multicolumn{3}{|c|}{ RSKD Province } & \multicolumn{3}{|c|}{$\begin{array}{c}\text { RSKD I.A } \\
\text { Pertiwi }\end{array}$} & \multicolumn{3}{|c|}{$\begin{array}{c}\text { RSKD I.A } \\
\text { Siti Fatimah }\end{array}$} \\
\hline & \multicolumn{9}{|c|}{ Patient Satisfaction } \\
\hline & \multirow[t]{2}{*}{$p$} & \multicolumn{2}{|c|}{$95 \% \mathrm{CI}$} & \multirow[t]{2}{*}{$p$} & \multicolumn{2}{|c|}{$95 \% \mathrm{CI}$} & \multirow[t]{2}{*}{$p$} & \multicolumn{2}{|c|}{$95 \% \mathrm{CI}$} \\
\hline & & Lower & Upper & & Lower & Upper & & Lower & Upper \\
\hline Mechanic Clues & .000 & 0.984 & 2.985 & .000 & 5.238 & 6.401 & .000 & 2.821 & 4.992 \\
\hline Humanistic Clues & .226 & -1.497 & 1.220 & .000 & 3.505 & 6.034 & .000 & 4.009 & 7.289 \\
\hline
\end{tabular}




\begin{tabular}{|l|l|l|l|l|l|l|l|l|l|}
\hline Perceived Value & .000 & -5.201 & -1.661 & .000 & 3.505 & 6.034 & .000 & 4.009 & 7.289 \\
\hline
\end{tabular}

Source: Primary data, 2020

Table 2 explains the percentage of respondents' assessment of the research variables. functional clues variable by looking at the value of $\mathrm{p}=0.000<0.05$ for RSKD IA Siti Fatimah and seeing the value of $\mathrm{p}=0.000<0.05$ for RSKD IA Pertiwi so it can be concluded that there is an influence between variable functional clues on patient satisfaction. The mechanic clues are variable on the patient satisfaction variable, where based on the table it can be seen that the value of $p=0.000<0.05$ for RSKD IA Siti Fatimah and the value is seen is the value of $p=0.000$ $<0.05$ for RSKD IA Pertiwi so that it can be concluded that there is an influence between variables mechanic clues on patient satisfaction. The human clues are variable on the patient satisfaction variable, where based on the table it can be seen that the value of $p=0.000<0.05$ for RSKD IA Siti Fatimah and the value is seen is the value of $p=0.000<0.05$ for RSKD IA Pertiwi so that it can be concluded that there is an influence between variables humanistic clues to patient satisfaction. Perceived value variable for patient satisfaction variable, which is based on the table it can be seen that the value of $\mathrm{p}=0.000<0.05$ for RSKD IA Siti Fatimah and the value of $\mathrm{p}=0.000<0.05$ so it can be concluded that there is an influence between the variable perceived value on patient satisfaction.

Table 3. Effect of Service Experience Simultaneously on Patient Satisfaction in Inpatient Installation of RSKD I.A South Sulawesi Province

\begin{tabular}{|c|c|c|c|c|c|c|}
\hline Variable & B & S.E & Wald & df & Sig. & Exp(B) \\
\hline RSKD Pertiwi & \multicolumn{7}{|l|}{} \\
\hline $\begin{array}{c}\text { Functional } \\
\text { Clues }\end{array}$ & 1.438 & 0.860 & 2.793 & 0.095 & 4.212 & 1.438 \\
\hline Mechanic Clues & 21.856 & 1.957 & 0.089 & 0.999 & 3.100 & 21.856 \\
\hline Humanic Clues & 1.721 & 0.830 & 4.298 & $\mathbf{0 . 0 3 8}$ & $\mathbf{5 . 5 9 1}$ & 1.721 \\
\hline $\begin{array}{c}\text { Perceived } \\
\text { Value }\end{array}$ & 1.681 & 0.926 & 3.298 & 0.069 & 5.370 & 1.681 \\
\hline RSKD Fatimah & & & & \\
\hline $\begin{array}{c}\text { Functional } \\
\text { Clues }\end{array}$ & 1.645 & 0.973 & 2.862 & 0.091 & 5.183 & 1.645 \\
\hline Mechanic Clues & 1.171 & 1.055 & 1.230 & 0.267 & 3.224 & 1.171 \\
\hline Humanic Clues & 2.880 & 0.985 & 8.544 & $\mathbf{0 . 0 0 3}$ & $\mathbf{1 7 . 8 1 1}$ & 2.880 \\
\hline $\begin{array}{c}\text { Perceived } \\
\text { Value }\end{array}$ & 1.631 & 0.896 & 3.314 & 0.069 & 5.107 & 1.631 \\
\hline Variable(s) entered on step 1: KAT_A, KAT_B, KAT_C, KAT_PV. \\
\hline
\end{tabular}

Source: Primary data, 2020

Table 3 shows that based on the data table, it can be seen that the results of multiple logistic regression tests of functional clues, mechanic clues, and humanistic clues on patient satisfaction at the Siti Fatimah Inpatient Installation of South Sulawesi Prov. $0.003<0.05$, so it can be concluded that the mechanic clues variable has a greater influence on patient satisfaction in the Inpatient Installation of RSKD IA Siti Fatimah, South Sulawesi Province. The results of multiple logistic regression test variables functional clues, mechanic clues, and humanistic clues on patient satisfaction at the Pertiwi Provincial Hospital of South Sulawesi, it was found that the 
variable that had the greatest influence was the humanistic clues variable with a value of $\mathrm{p}=$ $0.038<0.05$ so it can be concluded. that the humanistic clues variable has a greater influence on patient satisfaction in the Inpatient Installation of RSKD IA Pertiwi, South Sulawesi Province.

Service experience or service experience comes from a series of interactions between customers and service providers. Helkkula \& Kelleher (2010) define service experience as the core of a service offered and service design. Haeckel et al (2003) defines service experience as an impression or perception that is created as long as a customer consumes a product or service. The service experience is influenced by sensory and emotional clues.

Functional clues are quantities related to technical service quality, reliability and functionality. Functional clues can be considered as the competence of a service provider. Functional Clues/functional clues are at the core of every service because they bring customers to a service provider to solve their problems, or in other words, through these instructions, the service provider can meet customer expectations because of the service functionality aspects that offer core solutions to expectations. customers (Berry, 2006). Bhandari (2017) says that customers capture functional clues regarding reliability and function of service providers by using their brain logic circuits. In a study conducted by Keaveney (2013) on why customers abandon one service supplier for another, Keaveney found that 44 percent of the sample switched due to core service failures.

The results of the Mann Whitney test showed a significant influence on the functional clues variable on patient satisfaction at the Inpatient Installation of RSKD IA Pertiwi with a value of $p$ $=0.000<0.05$, which is the same as the logistic regression test results at RSKD IA Siti Fatimah which showed a significant effect. on the functional clues variable on patient satisfaction with a value of $p=0.000<0.05$. This research is in line with research by Borishade (2017) which states that there is an effect of functional clues on service experience on customer satisfaction. Fulfilling customer expectations on functional clues create a feeling of satisfaction with customers so that customers are interested in returning to using the product or service again. Functional clues influence a customer's cognitive or calculative perception of service quality, knowing functional clues and managing them well is fundamental to meeting customer service expectations, because functionality offers a core solution that customers buy but usually does not exceed customer service expectations.

Mechanic clues are conditions of service environment that involve aspects of sight, sight, smell and taste or physical appearance of service institutions. Function clues focus on the reliability of the service, mechanic clues focus on the sensory performance of the service. Mechanical clues coming from inanimate objects will provide a physical representation of the intangible service. Customers cannot directly see the competence of service providers but can see the existing mechanical instructions (Berry, 2006).

The results of the Mann Whitney test showed a significant influence on the mechanic clues variable on patient satisfaction at the Inpatient Installation of RSKD IA Pertiwi with a value of $p$ $=0.000<0.05$, the same as the logistic regression test results at RSKD IA Siti Fatimah which showed a significant effect. on the mechanic clues variable on patient satisfaction with a value of $\mathrm{p}=0.000<0.05$. This research is in line with Yulianti's research (2017) which found that mechanic clues have an effect on customer satisfaction in the Inpatient Installation of A.M Parikesit Hospital. It is explained that if the customer feels the condition of the service environment that involves aspects of sight, sight, smell and taste or physical appearance of the 
service institution is good, the level of satisfaction will also be good. Mechanic clues play an important role in making a positive first impression on a customer because in service consumption, the customer buys the service before actually experiencing it. Part of the first impression that mechanical cues play is the impact on customer service expectations.

Humanic clues are conditions related to the behavior and appearance of service providers, for example how to speak and body language, tone of voice, level of enthusiasm and dress appropriateness. Officer behavior affects satisfaction because customers evaluate interactions holistically and the perceptions that arise during service are an important key in realizing customer satisfaction (Turkay \& Sengul, 2014). Most of the respondents have a positive impression of humanistic clues. This is indicated by what respondents expressed in the openended research question that doctors who treat patients are friendly and polite, always greeting patients and their families. It is also stated that nurses are always responsive to the patient's condition, friendly and always present when needed.

The results of the Mann Whitney test showed a significant influence on the humanistic clues variable on patient satisfaction at the Inpatient Installation of RSKD IA Pertiwi with a value of $p$ $=0.000<0.05$, which is the same as the logistic regression test results at RSKD IA Siti Fatimah which showed a significant effect. on the humanistic clues variable on patient satisfaction with a value of $p=0.000<0.05$. This research is in line with Yulianti's research (2017) which found that humanistic clues have an effect on customer satisfaction in the Inpatient Installation of the A.M Parikesit Hospital. It is explained that if customers accept good attitudes and behavior from service providers, they will feel satisfied (Yulianti, 2017).

Perceived value as an overall consumer assessment of the usefulness of a product or service based on perceptions of what is received and what is given. Zeithaml \& Parasuraman (1994) found that some consumers get the value of all the components obtained in exchange for the price paid. Perceived value is the consumer's perception of what they (customers) get in return for what they provide (Bea, 2018).

The results of the Mann Whitney test showed a significant influence on the perceived value variable on patient satisfaction in the Inpatient Installation of RSKD IA Pertiwi with a value of $p$ $=0.000<0.05$, which is the same as the logistic regression test results at RSKD IA Siti Fatimah which showed a significant effect. on the humanistic clues variable on patient satisfaction with a value of $\mathrm{p}=0.000<0.05 \mathrm{H}$. Wu et al (2016) conducted a study on 452 medical tourist respondents from China with the results finding that perceived value has a positive effect on patient satisfaction. In addition, several studies also show that satisfaction is strongly influenced by perceived value (Cronin et al., 2000). Perceived value is one of the most important elements for gaining competitive advantage and is considered a significant predictor of satisfaction. High customer perceived value ensures customer satisfaction and customer loyalty.

\section{Conclusion}

Service experience based on functional clues, mechanic clues, humanistic clues, Perceived Value variables has an effect on patient satisfaction and humanistic clues variables that have the greatest influence on patient satisfaction both in the Inpatient Installation of RSKD for Mother and Children in South Sulawesi Province and at RSKD Ibu and Child of South Sulawesi Province Pertiwi and RSKD Mother and Child Siti Fatimah. It is recommended that each officer, both management and all employees, maintain the dimensions of a good service experience, try to meet expectations, wants and needs according to hospital standards, especially in the 
functional clues and humanistic clues dimensions by increasing the sensitivity of nurses in handling/care that can help complaints Patients, There needs to be an increase in strategies in building customer value so that patients feel the pride felt by patients when they are treated in the hospital.

\section{References}

Akbar, F. H., \& Pratiwi, R. (2016). Patient satisfaction against the quality of dental health services at dental polyclinic of Tenriawaru General Hospital in Bone Regency. $J$ dentomaxillofac sci, 1(3), 352-60.

Berry, L. L., Wall, E. A., \& Carbone, L. P. (2006). Service clues and customer assessment of the service experience: Lessons from marketing. Academy of Management Perspectives, 20(2), 43-57.

Bhattarai, N. (2017). Human resource development in government organizations of Nepal (Doctoral dissertation). Faculty of Management, Tribhuvan University.

Borishade, T. T. (2017). Customer Experience Management And Loyalty In Healthcare Sector: A Study Of Selected Private Hospitals In Lagos State, Nigeria. Doctoral dissertation, Covenant University, Ota, Nigeria.

Casper, J. K., \& Leonard, R. (2006). Understanding voice problems: A physiological perspective for diagnosis and treatment. Lippincott Williams \& Wilkins.

Chiang, C. and Lee, L. (2013). An Examination of Perceived Value Dimensions of Hotel Visitors : Using Exploratory and Confirmatory Factor Analyses, The Internasional Journal of Management Studies, 8(1), 167-174.

Cronin Jr, J. J., Brady, M. K., \& Hult, G. T. M. (2000). Assessing the effects of quality, value, and customer satisfaction on consumer behavioral intentions in service environments. Journal of retailing, 76(2), 193-218.

Guo, M. (2012). Service Experience from Customers Point of view. Aarhus School of Business.

Haeckel, S. H., Carbone, L. P., \& Berry, L. L. (2003). How to Lead the Customer Experience. Marketing Management, 12(1), 18-23.

Haeckel, S. H., Carbone, L. P., \& Berry, L. L. (2003). How to lead the customer experience. Marketing Management, 12(1), 18-18.

Helkkula, A., \& Kelleher, C. (2010). Circularity of customer service experience and customer perceived value. Journal of customer behaviour, 9(1), 37-53.

Huei, C. T., Mee, L. Y., \& Chiek, A. N. (2015). A study of brand image, perceived service quality, patient satisfaction and behavioral intention among the medical tourists. Global Journal of Business and Social Science Review, 2(1), 14-26.

Keaveney, A. (2013). Sulla: the last republican. Routledge.

Moliner, M. A. (2009). Loyalty, perceived value and relationship quality in healthcare services. Journal of service management.

Péfoyo, A. J. K., \& Wodchis, W. P. (2013). Organizational performance impacting patient satisfaction in Ontario hospitals: a multilevel analysis. BMC research notes, 6(1), 509. 
Prabhu, S., \& Kazi, R. (2016). Literature Review of Service Encounter Management, using Emotions Management. Indian Journal of Science and Technology, 9, 45.

Surydana, L. (2017). Service quality, customer value and patient satisfaction on public hospital in Bandung district, Indonesia. International Review of Management and Marketing, 7(2), 187-192.

Turkay, O., \& Sengul, S. (2014). Employee behaviors creating customer satisfaction: A comparative case study on service encounters at a hotel. European Journal of Tourism, Hospitality and Recreation, 5(2), 25-46.

Wu, H. C., Li, T., \& Li, M. Y. (2016). A study of behavioral intentions, patient satisfaction, perceived value, patient trust and experiential quality for medical tourists. Journal of Quality Assurance in Hospitality \& Tourism, 17(2), 114-150.

Yulianti, M. (2017). Pengaruh Service Experience terhadap Kepuasan Pelanggan di Instalasi Rawat Inap RSUD A.M Parikesit Kabupaten Kutai Kartanegara. Magister Administrasi Rumah Sakit Prodi Kesmas Universitas Hasanuddin.

Zarei, E., Daneshkohan, A., Pouragha, B., Marzban, S., \& Arab, M. (2015). An empirical study of the impact of service quality on patient satisfaction in private hospitals, Iran. Global journal of health science, 7(1), 1.

Zeithaml, V. A., \& Parasuraman, A. (1994). Reassessment of expectations as a comparison standard in measuring service quality: Implications. Journal of marketing: A quarterly publication of the american marketing association, 58(1), 111-124. 